\title{
Is Exchange Rate Volatility An Important Determinant Of Tax Revenues? Evidence From Turkey
}

\author{
Sinem Koçak ${ }^{1}$
}

\begin{abstract}
Is exchange rate volatility an important determinant of tax revenues? This study seeks, in the light of this question, empirical evidence on the relationship between volatility in exchange rates and tax revenues in the case of Turkey. Monthly data on exchange rate volatility, tax revenues, industrial production index and inflation rate for the period 2006:01-2019:12 are utilized for research purposes. The short-run and longrun dynamics between the variables are analyzed using the Autoregressive Distributed Lag (ARDL) model to shed some light on the macroeconomic determinants of tax revenues, with a new perspective considering exchange rate volatility. The results of the ARDL bounds test show that volatility in the exchange rate has a negative effect on tax revenues in the long-run, but positively in the short-run.
\end{abstract}

Keywords: Exchange Rate Volatility, Tax Revenues, ARDL bounds testing approach, Toda-Yamamoto approach, Turkey

JEL Codes: C32, E62, H2O

DOI: $10.24818 / \mathrm{REJ} / 2021 / 81 / 03$

\section{Introduction}

Taxes are one of the most important policy instruments for directing economic activity, as well as a significant financial source for the government. Taxes, paid by people, companies or organizations as a legal responsibility to the government, are used to rebuild public goods and services for both economic growth and the social advancement of the citizens. Taxes play a vital role for both citizens and governments because of this mutally bilateral structure.

However, for economies, economic structure has always been the most significant factor in the success of tax revenues. Tax revenues may also be affected by any change in economic conditions. (Tanzi, 1989; Chen and Hung, 2010; Lendvai,

${ }^{1}$ Ph.D.,Trabzon, ORCID ID: 0000-0002-2313-0161.Turkey, e-mail:sinemakcay@hotmail.com.tr

Year XXIV no. 81

September 2021 
Raciborski and Vogel, 2013; Çebi and Çulha, 2017). It is therefore useful to determine the macroeconomic determinants of tax revenue for this purpose. The relationship between tax revenues and major economic variables such as gross domestic product (GDP) per capita or income taken as a proxy for economic growth, foreign aid, inflation (INF. unemployment, real exchange rate, share of GDP in both agriculture and industry, and trade openness as a proxy for trade liberalization has therefore been subject to various theoretical and empirical considerations. (Lotz and Morss, 1970; Tanzi, 1989; Gupta, 2007; Karagöz, 2013; Harahap, Sinaga, Manurung and Maulana, 2018; Yıldız, 2019; Sağdıç, 2019; Bayar and Çelik, 2019). But so far, except for Ofori, Obeng and Armah (2018. the relationship between exchange rate volatility and tax revenues has not been explored in both theoretical and empirical contexts. Ofori, Obeng and Armah (2018) empirically studied the effect of exchange rate volatility on tax revenues for Ghana for the first time by using time series analysis. The findings obtained from the cointegration test have shown that volatility in the exchange rate has a negative impact on tax revenues both in the short-run and long-run.

Particularly in developing and fragile economies such as Turkey, high exchange rate volatility, stemed from both internal and external factors, is the most important variable affecting economic structure and with this changing performance of economy, tax revenues may be affected directly or indirectly by macroeconomic variables including imports, real output, industrial production, domestic consumption, employment and inflation. In past decade, it is noteworthy that exchange rate is highly volatile in Turkey. The currency shock that emerged in August 2018 in the economy and the long-lasting quite high volatility of exchange rate after this period caused a serious disruption ending up with high inflation and higher interest rates in the economy, because of its high imports dependency of production and high private sector external debt stock. Moreover, it has been seen that this quite remarkable volatility of exchange rate has also an effect on economic variables which have not been previously discussed by any studies. Just after that, policy makers immediately had to took a series of fiscal measure to balance the economy by increasing fiscal discipline beside monetary measures. As is seen from this period not only monetary policy but also fiscal policies, especially tax policies, were effectively utilised to correct the imbalances in the Turkey's economy. So, these policy implementations revealed the need to investigate the question of whether exchange rate volatility has an effect on tax revenues or not.

However, as stated earlier, the relationship between volatility in the exchange rate and tax revenues has not yet been explored by economists at the theoretical level and even at the empirical level. But studies have been done to investigate the 
relationship between the real exchange rate and tax revenues, not the volatility of the exchange rate. For any given country, Tanzi (1989) indicates a negative relationship between the real level of the exchange rate and tax revenues. The relationship between the real exchange rate and tax revenues emerges, according to Tanzi, directly from the effects of the appreciation of the exchange rate on import duties, export taxes, sales taxes and excise taxes. In addition, an overvalued exchange rate has a direct effect on both import duty revenue and other tax revenue. However, an overvalued exchange rate often has some indirect effect on tax revenues by decreasing incentives to generate products for export, by raising the possibility of a significant future devaluation or by limiting the flow of goods and capital. Furthermore, it is a fact that volatility in exchange rates has a close relationship with both exports and imports. Volatility in exchange rates often has a direct adverse effect on consumption by triggering inflation volatility (BahmaniOskooee, Kutan and Xi, 2015). Exchange rate volatility thus has the incredible ability, through these direct and indirect channels, to alter tax revenues. Tax collections are often influenced by macroeconomic factors, such as GDP and inflation, as stated in economic theory. If the level of development of a country rises, the tax base will both broaden and the government's tax collection capacity will increase. Both the ability of the government to collect taxes and the ability of people to pay taxes are increasing in countries that have a higher level of economic growth. The presence of a positive relationship between GDP and tax revenues is thus expected. It is also assumed that an increase in GDP would lead to a rise in tax revenues.

Economic theory, on the other hand, indicates that inflation and tax revenues have a negative relationship. Inflation by consumption, investment and other related taxes is expected to have a direct negative impact on real tax revenues. This effect is also known as Tanzi effect (1977) in the literature. The Tanzi effect is defined as the corressive outcomes of inflation on the real value of tax revenues. Due to the existence of collection lags for all tax payments and the size of the lag, the goverment is confronted with a real revenue loss in a period of high inflation. Thus, it is expected that inflation incurs a negative effect on tax revenuesThe linkage between inflationary policies and tax revenues is therefore of even greater importance to governments and, indirectly, to central banks, whose primary objective is to achieve and maintain price stability.

While it seems possible that the relationship between volatility in exchange rates and tax revenues may exist, the existence of this relationship for Turkey has not yet been empirically examined in the literature. From this point of view, the purpose of 
this paper is to seek proof as to whether or not exchange rate volatility has any effect on tax revenues, for the first time in the short-run and long-run, in the case of Turkey. The Toda-Yamamoto causality test is used, following the ARDL cointegration technique, to verify the presence of causal relationships between volatility in the exchange rate and tax revenues. The contribution of this research to literature is thus three-fold. First, this is the first research to investigate in the literature the relationship between the exchange rate volatility and Turkey's real tax revenues. Secondly, the research adds to the literature by describing both the shortrun and long-run effects of the volatility in exchange rates on Turkey's real tax revenues. Finally, this report is the first to explore the causal relationship between volatility of exchange rates and tax revenue. Therefore, by investigating tax revenue determinants with a new perspective, the research sheds light on the literature and on policymakers. Monthly data on macroeconomic variables over the period of 2006:01-2019:12 are utilised to carry out estimation.

Three key sections are part of the document. The literature review is the focus of the first section, and the second part outlines the data and econometric methods used in this study. Empirical results and concluding remarks are reflected in the last section.

\section{Literature Review}

Ofori, Obeng and Armah (2018) were the first and only studies examining the effects of exchange rate volatility on tax revenues using annual data from 1980 to 2014. The results of the ARDL method claim that exchange rate volatility has a negative impact on Ghana's tax revenues. The Granger causality test was carried out to establish the causal relationship among exchange rate volatility, tax revenues and control variables after determining the long-run relationship between exchange rate volatility. The causality test results proved a unidirectional causality from exchange rate volatility to tax revenues, a unidirectional causality from the share of industry to tax revenues. Finally a unidirectional causality from tax revenues to foreign aid was detected in the paper.

There are, however, a large number of studies in both theoretical and empirical literature seeking to point out the main or macroeconomic determinants of tax revenue. Following the Hinrich's (1965) paper, found the correlation between tax level differences and degree of openness, Lotz and Morss (1970) investigated the factors which affect tax level in developing countries. The results showed that the presence of taxable bases in developed countries is more significant than variations in demand for government expenditure. In a theoretical framework for developing 
countries, Tanzi (1989) concentrated on the macroeconomic determinants of taxation levels, classifying them as statistical determinants, institutional or social determinants and tax policy determinants. But these macroeconomic determinants only include the relationship between the real exchange rate and tax revenues, not the volatility of the real exchange rate. In this time, Tanzi and Davoodi (2000) showed empirically that the share of GDP in agriculture has a negative effect on tax revenues, but per capita income has a positive effect on tax revenues. By utilizing Generalized Method of Moment (GMM) regression Agbeyegbe, Stotsky and WoldeMariam (2004) found that trade liberalization is weekly linked to total tax revenues. The results for currency appreciation and higher inflation indicated some lower tax revenues. Gupta (2007) showed in another paper for developing countries that per capita GDP, GDP in agriculture, trade openness and foreign aid have a major impact on revenue performance in any economy. In the case of Pakistan, Chaudhry and Munir (2010) demostrated that openness, broad money, external debt, foreign aid and political stability have the significant effect on tax revenues with expected signs. The findings of Addison and Levin (2012) for 39 sub-Saharan African countries over the period 1980-2005 showed that the effect of the share of agriculture sector on total tax revenue GDP ratio is negative and statistically significant, but openness has a statistically positive significant effect on total tax revenue GDP ratio. For another variable, per capita GDP has a positive but insignificant effect on total tax revenue ratio. By using fixed and random effects models, Gaalya (2015) proved that exchange rates, share of industry to GDP and especially trade openness have positive effects on tax revenue performance, while the agriculture share to GDP and foreign aid have negative effects for Uganda over the period of 1994-2012. More recently a study by Yildız (2019) demonstrated that per capita of GDP which was statistically significant affected tax revenues positively in 19 high income OECD countries for the period of 1995-2017. On the other hand the effect of public expenditures and aggricultural value added on tax revenues for these OECD countries were statistically significant and negative. For the 1991-2015, another analysis for OECD countries was used by Çalcalı and Altıner (2019). The results of the Panel AMG approach showed that in most countries, unemployment and economic growth had no impact on tax revenues, while inflation had a negative impact and economic globalization had a positive impact on tax revenues.

Turkey has a limited number of papers seeking to empirically analyze the determinants of tax revenues. In addition, the relationship between exchange rate volatility and tax revenues has not yet been empirically tackled or explored in these studies. For Turkey, in general, the relationship among tax revenues and economic growth, tax rates, public expenditure and corruption has been studied. (Yamak and 
Yamak, 1995; Karabulut, 2006; Durkaya and Ceylan, 2006; Mucuk and Alptekin, 2008; Temiz, 2008; Karagöz and Mutlu, 2009; Yamak and Abdioğlu, 2012; Dökmen, 2012; Erdoğan, Topçu and Ozan, 2013; Altunöz, 2017; Songur and Yüksel, 2018; Akınc1, 2019; Boğa, 2020). For the period 1970-2010, Karagöz (2013) concentrated its sectoral composition on Turkey in order to evaluate the main tax revenue factors. The results of the regression analysis revealed that the share of GDP in agriculture and industry, external debt stocks, the rate of urbanization and finally the level of monetization have an effect on tax revenues. Another study for Turkey's economy came from Atsan (2017) by employing multiple regression analysis for the years of 1984 and 2012. His results showed that foreign trade affects tax revenues positively, while the agricultural value added has a negative effect. Öztürk, Şaşmaz, Bayar and Odabaş (2019) investigated the effect of major economic variables on tax revenues for the case of Turkey during 1980-2017. The findings demonstrated that economic growth and urbanization have a positive effect on tax revenues, but negative for unemployment, shodow economy and inflation. The relationships of tax revenues with GDP per capita, the shares of industry, the service sectors in GDP and openness on a regional scale for the period of 1990-2001 and 2004-2011 was also examined by Sağdiç (2019). The results of panel data analysis indicated that all economic variables affect positively tax revenues for Turkey, but the effect of agriculture sector on tax revenues is only negative.

\section{Data And Methodology}

In this study, monthly data on macroeconomic variables over the period of 2006:012019:12 are utilised to carry out estimation for Turkey. The data for tax revenues (TR. consumer price index (CPI) $(2003=100$. industrial production index (IPI) $(2015=100)$ and CPI based real effective exchange rate (REER) $(2003=100)$ were compiled from the Electronic Data Delivery System of the Central Bank of the Republic of Turkey. Before starting the analysis, tax revenues, industrial production index and consumer prices index were seasonally adjusted using Census X-12 process and then consumer price index is used to both deflate tax revenues to obtain real tax revenues (RTR) and define inflation rate (INF). On the other hand, industrial production index used as a monthly leading indicator of GDP and inflation rate are included in the analysis as control variables which are broadly consistent with economic theory and previous empirical studies (Tanzi, 1989; Gupta, 2007; Ofori, Obeng and Armah, 2018). A logarithmic transformation expressed with the letter $\mathrm{L}$ in front of the variables for all data was realized after this process. The moving standard deviation of the growth rate of the real effective exchange rate is used as a first step in the analysis to achieve volatility in the exchange rate (EXV). The EXV is implemented as follows:

Year XXIV no. 81

September 2021 


$$
\operatorname{EXV}_{\mathrm{t}}=\left[\left(\frac{1}{\mathrm{~m}}\right) \sum_{\mathrm{i}=1}^{\mathrm{m}}\left(\mathrm{LREER}_{\mathrm{t}+\mathrm{i}-1}-\mathrm{LREER}_{\mathrm{t}+\mathrm{i}-2}\right)^{2}\right]^{1 / 2}
$$

where LREER is the logarithm of the real effective exchange rate and the order of the moving avarage, $\mathrm{m}$ is set to equal to 12 . The ARDL cointegration technique developed by Pesaran and Shin (1999) was applied in the second step after obtaining the exchange rate volatility series to investigate the long-run relationship between real tax revenues and volatility in the exchange rate. The ARDL cointegration technique has the benefit of not having both pre-tests for unit roots in all cointegration tests, all variables must be $\mathrm{I}(0$. (1) or a mixture of both, and it also provides the model's short-run and long-run dynamics at the same time. The subsequent regression describes the ARDL model.

$$
\begin{gathered}
\Delta \mathrm{LRTR}_{\mathrm{t}} \alpha_{0}+\sum_{\mathrm{i}=1}^{\mathrm{p}} \beta_{\mathrm{i}} \Delta \mathrm{LRTR}_{\mathrm{t}-\mathrm{i}}+\sum_{\mathrm{i}=0}^{\mathrm{q}} \varphi_{\mathrm{i}} \Delta \mathrm{EXV}_{\mathrm{t}-\mathrm{i}}+\sum_{\mathrm{i}=0}^{\mathrm{m}} \gamma_{\mathrm{i}} \Delta \mathrm{LIPI}_{\mathrm{t}-\mathrm{i}} \sum_{\mathrm{i}=0}^{\mathrm{n}} \theta_{\mathrm{i}} \Delta \mathrm{INF}_{\mathrm{t}-\mathrm{i}}+ \\
\delta_{1} \mathrm{LRTR}_{\mathrm{t}-1}+\delta_{2} \mathrm{EXV}_{\mathrm{t}-1}+\delta_{3} \mathrm{LIPI}_{\mathrm{t}-1}+\delta_{4} \mathrm{INF}_{\mathrm{t}-1}+\delta_{5} \mathrm{DUMMY} \varepsilon_{1 \mathrm{t}}
\end{gathered}
$$

where the coefficients $\beta_{i}, \varphi_{i}, \gamma_{i}$ and $\theta_{i}$ represent the short-run dynamics of the variables and the coefficients $\delta_{i}$ represent the long-run elasticities. $\Delta$ is the first difference operator and DUMMY is the dummy variable to account for a structural change for the model. The null hypothesis after estimating the regression equation (2) is that no cointegration between variables is evaluated using F-statistics against the alternative hypothesis of the existence of cointegration.

The Augmented Granger causality test developed by Toda and Yamamoto (1995) is used to test the causal relationship between the variables in the last phase, after verifying the existence of long - run relationship between real tax revenues and exchange rate volatility. The system of Toda and Yamamoto based on Augmented VAR model estimation $\left(k+d_{\max }\right)$ contains two types of lag lengths where $\mathrm{k}$ is the optimal lag length on the standard VAR model and $\mathrm{d}_{\max }$ is the maximum integrated order of the variables in the standard VAR model. The null hypothesis after estimating the VAR system is that the volatility of the exchange rate, EXV, does not cause real tax revenues, LRTR, is checked by applying the Wald test against the alternative hypothesis. 


\section{Empirical Findings}

Although the unit root properties of the variables are not needed in the ARDL method, a pre-test of the unit root must be performed to ensure that the order of the integration of variables is not greater than I (1). Therefore, unit root tests were first used for the variables by Augmented Dickey-Fuller (ADF) (Dickey and Fuller, 1979) and Phillips-Perron (PP) (1988). Table 1 shows the statistics of the ADF and PP unit root methods.

Table 1: The Results of Unit-Root Tests

\begin{tabular}{ccccc}
\hline Variables & \multicolumn{2}{c}{ ADF Unit-Root Test Results } & \multicolumn{2}{c}{ PP Unit-Root Test Results } \\
\hline & Constant & Constant+Trend & Constant & Constant+Trend \\
\hline EXV & $-3.938^{* * *}$ & $-4.022^{* * *}$ & $-3.902^{* * *}$ & $-3.908^{* * *}$ \\
\hline LRTR & 0.799 & -2.532 & -2.323 & $-10.529^{* * *}$ \\
\hline$\Delta$ LRTR & $-6.039^{* * *}$ & $-6.017^{* * *}$ & $-58.871^{* * *}$ & $-60.192^{* * *}$ \\
\hline LIPI & -0.563 & -2.083 & -1.480 & $-7.735^{* * *}$ \\
\hline$\Delta$ LIPI & $-15.434^{* * *}$ & $-15.381^{* * *}$ & $-34.387^{* * *}$ & $-34.272^{* * *}$ \\
\hline INF & $-9.641^{* * *}$ & $-9.135^{* * *}$ & $-9.693^{* * *}$ & $-9.744^{* * *}$ \\
\hline
\end{tabular}

Note: Lag length was selected by using Schwarz information criteria (SIC). $\Delta$ is the first difference operator. ${ }^{* * *}$,denotes significance level of $1 \%$.

The determined ADF and PP unit root test statistics for the level of EXV and INF, as stated in Table1, reject the null hypothesis that implies the existence of the unit root at the $1 \%$ significance level for exchange rate volatility and inflation. However, the calculated ADF and PP unit root tests statistics for the level of LRTR and LIPI can not be rejected the null hypothesis even at the $10 \%$ significance level, the alternative hypothesis for the first difference of LRTR and LIPI are separately accepted at the $1 \%$ level of significance. The results of the unit-root tests prove that EXV and INF are $\mathrm{I}(0$. while LRTR and LIPI are $\mathrm{I}(1)$. After detecting the unit root characteristics of the variables that have different integration orders, $I(0)$ and $\mathrm{I}$ (1. but not $\mathrm{I}(2$. it is shown that ARDL is the most appropriate tool for analyzing the long-run relationship between the variables. First, bounds test was performed in the sense of the ARDL method to test the presence of a long-run relationship between the variables. The ARDL bounds test results are summarized in Table 2 . Can be seen from the table, at the $1 \%$ significant level, the calculated F-statistic for the cointegration test, 64.170 , becomes quite greater than the upper bounds critical value. This result implies that the null hypothesis of no long-run relationship among 
the variables is rejected at the $1 \%$ significance level and so there is a long-run relationship among the variables.

Table 2: ARDL Bounds Test Results

\begin{tabular}{lll}
\hline & F-Statistics & Conclusion \\
\hline$F_{\text {LRTR }}=($ LRTR $\mid$ EXV , LIPI, INF $)$ & $64.170^{* * *}$ & Co-integrated
\end{tabular}

Note: ${ }^{* * *}$, denotes significance level of $1 \%$. Lag, $\mathrm{k}$, is 3 . Lower-bound critical value at $1 \%$ is 4.3 and Upper-bound critical value at $1 \%$ is 5.23 .

After detecting the presence of the long-run relationship between the variables, the short-run and long-run elasticities of the model are measured in the second stage of the ARDL cointegration technique and the results are provided in Table 3. First, it should be noted that all the ARDL model's calculated short-run and long-run coefficients are statistically significant at or mostly better than the $10 \%$ significance level, except for short-run elasticity of the EXV for the current period. Thus, it can be said that exchange rate volatility is playing a key role in tax revenue generation for Turkey. The estimated long-run coefficient of exchange rate volatility is found to be -2.732 and the coefficient is statistically significant at the $1 \%$ level. This coefficient of elasticity proves that the volatility of the exchange rate has a negative effect on real tax revenues. This result is in line with Ofori, Obeng and Armah (2018. but the size of the long-run elasticity of EXV for Turkey is about three times bigger than that of Ghana (-0.854). Namely, a 10 percent increase (decrease) in exchange rate volatility decrease (increase) real tax revenues by 27.32 percent in Turkey in the long-run. Similarly, in the long-run inflation rate has a negative effect on real tax revenues as expected in theory. The result supports the theoretical framework suggested by Tanzi (1977). The estimated elasticity coefficient of inflation rate implies that real tax revenues decreases (increase) by 2.40 percent if inflation rate increases (decrease) by 1 percent. On the other hand, the long-run elasticity of industrial production index is positive as expected in theory and statistically significance at the 1\% level. This coefficient implies that real tax revenues increases (decrease) by about 5 percent if industrial production index increases (decrease) by 10 percent. As a result, while exchange rate volatility and inflation rate have a detrimential effect on real tax revenues, industrial production index has an inducing effect in the long-run.

According to the error correction model that presents the short-run dynamics, the short-run elasticity of exchange rate volatility for current period is estimated as 0.712 , but it is not found statistically significant. On the other hand one-periodlagged coefficient of exchange rate volatility is found to be 5.327 and the coefficient 
is statistically significant at the $1 \%$ level. Unlike the long-run, in the short-run exchange rate volatility has a positive effect on real tax revenues and also the size of the short-run elasticity of the volatility is about two times bigger than the longrun. So, the short-run effect of exchange rate volatility is quite higher than that of long-run. The estimated short-run elasticity of industrial production index which is statistically significant at the $1 \%$ level is estimated as 0.422 . The short-run elasticity coefficient of industrial production index is almost the same in terms of the size with the long-run elasticity coefficient. But the short-run effect of inflation rate on real tax revenues, -0.906 , is about three times smaller than that of long-run in the current period. Hoewever, one-period-lagged coefficient of inflation rate, 2.716, is found to be positive and the coefficient is statistically significant at the $1 \%$ level. The coefficient of the error correction term is statistically significant at the $1 \%$ level with negative sign as expected. The value of -1.324 of error correction term implies that the error correction process fluctuates around the long-run value in a dampening manner instead of monotonically converging to the equilibrium path directly (Narayan and Smyth, 2006).

Table 3: Long-Run and Short-Run Estimates of ARDL $(1,2,1,3)$

\begin{tabular}{|c|c|c|c|}
\hline Variable & $\begin{array}{c}\text { Short-Run } \\
\text { Coefficients }\end{array}$ & Variable & $\begin{array}{l}\text { Long-Run } \\
\text { Coefficients }\end{array}$ \\
\hline$\Delta \mathrm{EXV}_{\mathrm{t}}$ & -0.712 & $\mathrm{EXV}_{\mathrm{t}}$ & $-2.732^{* * *}$ \\
\hline$\Delta \mathrm{EXV}_{\mathrm{t}-1}$ & $5.327^{* * *}$ & $\mathrm{LIPI}_{\mathrm{t}}$ & $0.481^{* * *}$ \\
\hline$\Delta \mathrm{LIPI}_{\mathrm{t}}$ & $0.422^{* * *}$ & $\mathrm{INF}_{\mathrm{t}}$ & $-2.404^{* * *}$ \\
\hline$\Delta \mathrm{INF}_{\mathrm{t}}$ & $-0.906^{*}$ & TREND & $0.001^{* * *}$ \\
\hline$\Delta \mathrm{INF}_{\mathrm{t}-1}$ & $2.716^{* * *}$ & CONS & $12.513^{* * *}$ \\
\hline$\Delta \mathrm{INF}_{\mathrm{t}-2}$ & $1.287^{* * *}$ & & \\
\hline DUMMY & $0.044^{* * *}$ & & \\
\hline $\mathrm{ECT}_{\mathrm{t}-1}$ & $-1.324^{* * *}$ & & \\
\hline \multicolumn{4}{|c|}{ Diagnostic Tests Results of the ARDL Model } \\
\hline $\mathrm{R}^{2}: 0.73$ & & LM : 1.659 & \\
\hline BPG : 16.382 & & RESET : 0.01 & \\
\hline
\end{tabular}

Note: LRTR is the dependent variable of the model. ${ }^{* * *},{ }^{* *},{ }^{*}$ denote significance level of $1 \%, 5 \%$ and $10 \%$, respectively. The optimum ARDL model order is determined by the information criteria based on Schwarz information criteria (SIC). BPG is Breusch-Pagan-Godfrey test; LM is the BreuschGodfrey serial correlation test. RESET is the Ramsey's Reset test for misspecification of the model.

However, to check of the robustness of the model, parameter stability or structural change is tested by applying cumulative sum (CUSUM) and cumulative sum of squares (CUSUMSQ). Figures 1 present the CUSUM and CUSUMSQ of the model without dummy varriable. As can be seen from the Figures 1, the plots of both 
CUSUM and CUSUMSQ statistics does not stay within the critical bonds of $5 \%$ level of significance. So, the CUSUM and CUSUMSQ statistics indicated that there exist a structural change in 2011 and 2012 years. To eliminate the effects of structural changes from the model, the dummy variable which is equal to 1 for the period from March 2011 to February 2012 is included in the ARDL model. After including dummy variable in the model, as reported in Table 3 , the coefficient of dummy variable is found to be statistically significant at the $1 \%$ level and positive. As seen from the Figures 2, the plots of CUSUM and CUSUMSQ statistics stay within the critical bonds of $5 \%$ level of significance. Moreover, the plots of CUSUM and CUSUMSQ statistics show that there is no evidence for parameter instability in the model. Finally, the results of diagnostic tests that are presented in the second panel of Table 3 do not involve evidence of both serial correlation and heteroskedasticity for the model. The Ramsey's RESET test result shows that the model do not suffer from misspecification problem.

Figure 1: The CUSUM and CUSUM of Squares Tests (without DUMM)

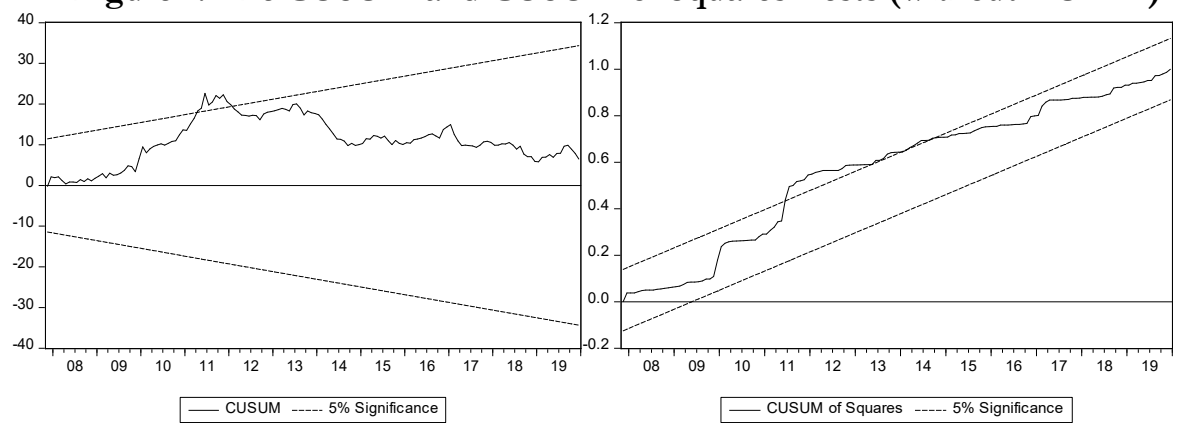

Figure 2: The CUSUM and CUSUM of Squares Tests (with DUMMY)
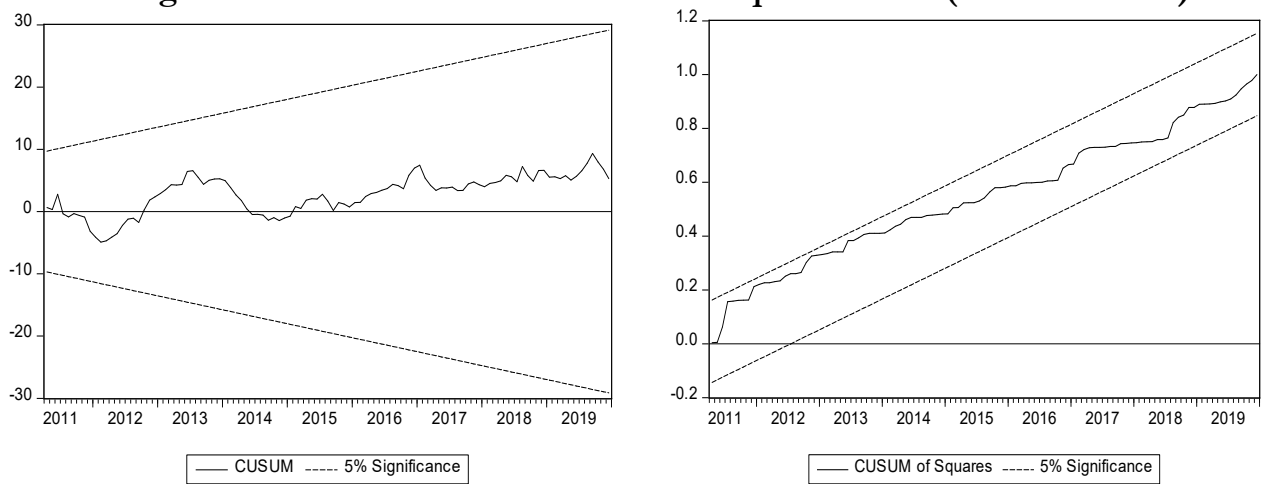

Year XXIV no. 81

September 2021 
Table 4 summarizes the findings of the Toda-Yamamoto causality test. The null hypothesis of no-causality from exchange rate volatility to real tax revenue, such as in Table 4 , is rejected at the level of $1 \%$ significance. But, the null hypothesis of nocausality from real tax revenues to exchange rate volatility is not rejected even at the $10 \%$ significance level. Thus, there is only a one-way causality from exchange rate volatility to real tax revenues. The causality test results between industrial production index and real tax revenues indicate that there exists a one-way causal relationship from industrial production index to real tax revenues, but not from real tax revenues to industrial production index. Finally, as seen from the TodaYamamoto approach to the results of the Granger causality test, there is also evidence of one-way causality from the inflation rate to the real tax revenue, while no evidence of causality from the real tax revenue to the inflation rate is accessible.

Table 4: Toda-Yamamoto Causality Test Results

\begin{tabular}{lll}
\hline \multicolumn{1}{c}{ Null Hypothesis } & \multicolumn{1}{c}{$\chi^{\mathbf{2}}$} & \multicolumn{1}{c}{ Result } \\
\hline EXV $\nrightarrow$ LRTR & $29.435^{* * *}$ & REJECT \\
\hline LRTR $\nrightarrow$ EXV & 1.096 & NOT REJECT \\
\hline LIPI $\nrightarrow$ LRTR & $8.349^{* *}$ & REJECT \\
\hline LRTR $\nrightarrow$ LIPI & 5.683 & NOT REJECT \\
\hline INF $\nrightarrow$ LRTR & $20.856^{* * *}$ & REJECT \\
\hline LRTR $\nrightarrow$ INF & 3.740 & NOT REJECT \\
\hline
\end{tabular}

Note: ${ }^{* * *}$ and ${ }^{* *}$, denote significance level of $1 \%$ and $5 \%$, respectively.

\section{Conclusions}

Many studies have investigated the main determinants of tax revenues in literature. Whereas exchange rate volatility plays a crucial role in affecting macroeconomic dynamics, especially in developing countries, none of these studies have so far focused on the relationship between tax revenues and exchange rate volatility, with the exception of Ofori, Obeng and Armah (2018). The underlying motivation of this paper, therefore, is to add to existing tax revenue literature by exploring, for the first time in Turkey, the relationship between exchange rate volatility and real tax revenue by using the cointegration approach of the Autoregressive Distributed Lag (ARDL). The paper is also intended to provide proof of both the short-run and long-run dynamics of the volatility of exchange rates on real tax revenues. In addition, this is the first investigation to establish the causal relationship between the volatility of exchange rates and Turkey's tax revenues.

Year XXIV no. 81

September 2021 
In this analysis, the relationship between volatility in exchange rates and tax revenues was mainly examined in the case of Turkey. However, the relationship between tax revenues, the GDP proxy index of industrial output and the inflation rate has also been analyzed. Monthly data for the period 2006:01-2019:12 is used to construct the analysis. The short-run and long-run effects of exchange rate volatility on tax revenues are examined by implementing ARDL bounds test. After determining the long-run relationship, Augmented Granger Causality test developed by Toda and Yamamoto is employed to determine the existence of the causal relationship between exchange rate volatility and tax revenues.

The findings of the ARDL bounds test show that there is a powerful long-run relationship between volatility in the exchange rate and tax revenues. The calculated elasticity coefficient of volatility in exchange rates shows that volatility in exchange rates has a negative effect on long-run tax revenues. This finding is in line with Ofori, Obeng and Armah (2018). Moreover, the existence of a long-run relationship between exchange-rate volatility and tax revenue implies that exchange-rate volatility is a strong macroeconomic determinant of tax revenue, and exchange-rate volatility often plays a major role in fiscal policy making, in addition to monetary policy. In addition, while the index of industrial production has a positive long-run impact on tax revenues, unlike Ofori, Obeng and Armah, the effect of the inflation rate on long-run tax revenues is negative and strong (2018). The long-run coefficients of both industrial production index and inflation rates are estimated with the expected signs as suggested in economic theory. The results for inflation rates also supports Tanzi effect for Turkey.

Nevertheless, the size of the long-run elasticity coefficients of both the volatility of the exchange rate and the rate of inflation has been found to be much greater than that of the index of industrial output. In view of Turkey's tax structure, the deleterious effect of the volatility of the exchange rate and the inflation rate on tax revenues is not surprising. In other words, the percentage of indirect taxes in overall tax revenues is approximately $62 \%$. In the case of indirect taxes, only the share of value-added tax and special consumption tax account for approximately $51 \%$ of overall revenuesMoreover, both the production dependency on imports and the pass-through exchange rate for inflation in Turkey are very high. Consequently, the suppressive effects of the volatility of the exchange rate on imports, inflation and consumption are likely to reduce the collection of import duties, export taxes, sales taxes and excise taxes, which are usually imposed on domestic and imported consumption. Policymakers mainly also need set policies that narrow down the foreign exchange gap in the economy and attract foreign direct investment in order 
to minimize exchange rate volatility. At this point, the policy instruments used by the Republic of Turkey's Central Bank to maintain price stability and low inflation rates are of great importance in order to protect the accountability and credibility of the central bank and boost tax revenues.

However, the short-run effect of exchange rate volatility on tax revenues is negative but not statistically significant in the current period. Unlike the current period, oneperiod-lagged coefficient of exchange rate volatility is both significantly positive and quite high. Also, this effect of exchange rate volatility on tax revenues is quite higher than that of long-run. To sum up, while exchange rate volatility has a positive effect on tax revenues in the short-run, the long-run effect of exchange rate volatility on tax revenues is negative. Besides, the short-run effect of industrial production index on tax revenues is positive but the short-run effect of inflation rate on tax revenues is negative. Therefore, the results of the study indicate that industrial production index, inflation rate and especially exchange rate volatility are strong determinants of tax revenues for Turkey.

The Toda-Yamamoto approach to Granger causality test results indicate that there exists a uni-directional causal relationship from exchange rate volatility to real tax revenues. Also, causality test results suggest the existence of a uni-directional causality from industrial production index to tax revenues and lastly support a unidirectional causality from inflation rate to tax revenues. These findings are close to those of Ofori, Obeng and Armah (2018).

\section{References}

Addison, T.; Levin, J., 2012. The determinants of tax revenue in Sub-Saharan Africa. Nationell Konferens i Nationalekonomi, Stockholm: 1-21.

Agbeyegbe, T.; Stotsky, J.G.; WoldeMariam, A., 2004. Trade liberalization, exchange rate changes and tax revenue in Sub-Saharan Africa. International Monetary Fund Working, Paper No. 04/178.

Akınc1, A., 2019. Vergi gelirlerinin ekonomik büyüme üzerindeki etkisi. Finans Ekonomi ve Sosyal Arastirmalar Dergisi, Vol. 4: 100-106.

Altunöz, U., 2017. Türkiye ekonomisi için vergi geliri-kamu harcamaları ilişkisinin ampirik analizi. Vergi Dünyası, Vol. 36, No. 433: 1-17.

Atsan, E., 2017. The determinants of tax capacity and tax effort in Turkey for the period of 1984-2012. Ömer Halisdemir Üniversitesi İktisadi ve İdari Bilimler Dergisi, Vol. 10, No. 4: pp. 214-234. 
Bahmani-Oskooee, M.; Kutan, A.M.; Xi, D., 2015. Does exchange rate volatility hurt domestic consumption?evidence from Emerging Economies. International Economies, Vol. 144: 53-65.

Bayar, Y.; Nazlı, E.Ç., 2019. Ticari serbestleşmenin vergi geliri etkisi: Türkiye örneği. Maliye Dergisi, Vol. 176: 428-440.

Boğa, S., 2020. Türkiye'de vergi gelirleri ve ekonomik büyüme arasındaki asimetrik ilişki: nardl eşbütünleşme yaklaşımı. Üçüncü Sektör Sosyal Ekonomi Dergisi, Vol. 55, No.1: 487-507.

Chaudhry, I. S.; Farzana, M. 2010. Determinants of low tax revenue in Pakistan. Pakistan Journal of Social Sciences, Vol. 30, No. 2: 439-452.

Chen, M.-C.; Chung-Yu, H. 2010. The effects of macroeconomic factors on implicit taxes: evidences from an Emerging Economy. Journal of International Accounting, Auditing and Taxation, Vol. 19: 79-92.

Çalcalı, Ö.; Ali, A., 2019. Makro ekonomik açıdan vergi gelirlerinin belirleyicileri: OECD ülkeleri üzerine bir uygulama. Maliye ve Finans Yazlar, Vol. 112: 175-198.

Çebi, C.; Çulha, A.A., 2017. How does economic activity affect tax revenues?. https://tcmbblog.org/wps/wcm/connect/blog/en/main+menu/analyses /how +does+economic +activity+affect+tax, [Accessed in May, 2020]

Dickey, A.D.; Wayne, A.F., 1979. Distribution of the estimators for autoregressive time series with a unit root. Journal of the American Statistical Association, Vol. 74: $27-431$.

Dökmen, G., 2012. Yolsuzlukların vergi gelirleri üzerindeki etkisi: dinamik panel veri analizi. Doğus Üniversitesi Dergisi, Vol. 13, No.1: 41-51.

Durkaya, M.; Ceylan, S., 2006. Vergi gelirleri ve ekonomik büyüme. Maliye Dergisi, Vol. 150: 79-89.

Erdoğan, E.; Topçu, M.; Ozan, B., 2013. Vergi gelirleri ve ekonomik büyüme ilişkisi: Türkiye ekonomisi üzerine eşbütünleşme ve nedensellik analizi. Finans Politik \& Ekonomik Yorumlar, Vol. 50, No.576: 99-109.

Gaalya, M.S., 2015. Trade liberalization and tax revenue performance In Uganda. Modern Economy, Vol. 6: 228-244.

Gupta, A.S., 2007. Determinants of tax revenue efforts in Developing Countries. IMF Working Paper No. 07-184.

Harahap, M.; Sinaga, B.M.; Manurung, A.H.; Maulana, T.N.A., 2018. Impact of policies and macroeconomic variables on tax revenue and effective tax rate of infrastructure, utility and transportation sector companies listed in Indonesia Stock Exchange. International Journal Of Economics And Financial Issues, Vol. 8, No. 3: 95-104. 
Hinrichs, H.H., 1965. Determinants of governments revenue shares among Less Developed Countries. Economic Journal, Vol. 75: 546-556.

Karabulut, T., 2006. Laffer etkisinin Türkiye uygulaması (1980-2003). Selçuk Üniversitesi Sosyal Bilimler Enstitïsü Dergisi, Vol. 16: 367-377.

Karagöz, K., 2013. Determinants of tax revenue: does sectorial composition matter?. Journal of Finance, Accounting and Management, Vol. 4, No. 2: 50-63.

Karagöz, K.; Mutlu, A., 2009. Vergi gelirleri kamu harcamaları ilişkisi Türkiye için bir zaman serileri analizi. Vergi Dünyas, Vol. 337: 28-135.

Lendvai, J.; Raciborski, R.; Vogel, L., 2013. Macroeconomic effect of an equity transaction tax in a general-equilibrium model. Journal of Economic Dynamics and Control, Vol. 37: 466-482.

Lotz, J.R.; Morss, E.R., 1970. A theory of tax level determinants for Developing Countries. Economic Development and Cultural Change, Vol. 18, No. 3: 328-341.

Mucuk, M.; Alptekin, V., 2008. Türkiye'de vergi ve ekonomik büyüme ilişkisi: var analizi (1975 - 2006). Maliye Dergisi, Vol. 155: 159-174.

Narayan, P.K.; Smyth, R., 2006. What determines migration flows of low-1ncome to High-Income Countries? An Empirical Investigation of Fiji-U.S. Migration 1972-2001. Contemporary Economic Policy, Vol. 24, No. 2: 332-342.

Ofori, I.K.; Obeng, C.K., Armah, M.K., 2018. Exchange rate volatility and tax tevenue: evidence from Ghana. Cogent Economics \& Finance, Vol. 6, No. 1: 117.

Öztürk, Ö.; Şaşmaz, M.Ü.; Bayar, Y.; Odabaş, H., 2019. Türkiye'de başlica ekonomik değișkenlerin vergi gelirleri üzerindeki etkisi: çoklu doğrusal regresyon analizi. Sayıştay Dergisi, Vol. 30: 37-53.

Pesaran, M.H.; Shin, Y., 1999. An autoregressive distributed lag modelling approach to cointegration analysis. S. Strom (Ed.) Econometrics and Eonomic Theory in the 20th Century: the Ragnar Frisch Centennial Symposium, Cambridge: Cambridge University Press.

Pesaran, M.H.; Shin, Y.; Smith, R.J., 2001. Bounds testing approaches to the analysis of level relationships. Joumal of Applied Econometrics, Vol. 16, No. 3: 289-326.

Phillips, P.C.B.; Perron, P., 1988. Testing for a unit root in time series regression. Biometrika, Vol. 75: 335-346.

Sağdıç, E.N., 2019. Vergi gelirlerini belirleyen faktörlerin bölgesel analizi: Türkiye Örneği. Dumlupinar Üniversitesi Sosyal Bilimler Dergisi, Vol. 60: 155-178.

Songur, M.; Yüksel, C., 2018. Vergi yapısı ile ekonomik büyüme arasındaki nedensellik ilişkisi: Türkiye Örneği. Finans Politik \& Ekonomik Yorumlar, Vol. 643: 47-70.

Tanzi, V., 1977. Inflation, lags in collection, and the real value of tax revenue. International Monetary Fund Staff Paper, Vol. 24, No. 1: 154-167.

Year XXIV no. 81

September 2021 
Tanzi, V., 1989. The impact of macroeconomic policies on the level of taxation and the fiscal balance in Developing Countries. Staff Papers, Vol. 36, No. 3: 633-656.

Tanzi, V.; Davoodi, H.R., 2000. Corruption, growth, and public finances. IMF Working Paper No., 00/182.

Temiz, D., 2008. Türkiye'de vergi gelirleri ve ekonomik büyüme ilişkisi: 1960-2006. 2. Ulusal İktisat Kongresi, İzmir.

Toda, H.Y.; Yamamoto, T., 1995. Statistical inference in vector autoregressions with possibly integrated processes. Journal of Econometrics, Vol. 66, No. 1: 225-250.

Yamak, N.; Yamak, R., 1995. Türkiye'nin vergi türlerine göre Laffer eğrisi. Ekonomik Yaklasim, Vol. 6, No. 18-19: 51-65.

Yamak, R.; Abdioğlu, Z., 2012. Ampirik bağlamda toplam ve alt kalemler bazında kamu harcamaları ve kamu gelirleri arasındaki ilişki: Türkiye Örneği. Hacettepe Üniversitesi İIBF Dergisi, Vol. 30, No.1: 173-193.

Yıldız, B. 2019. Vergi gelirlerinin ekonomik belirleyicileri üzerine ampirik bir analiz: yüksek gelirli OECD ülkeleri örneği. Yönetim ve Ekonomi Araştırmalar Dergisi, Vol. 17, No. 3: 324-339. 